\title{
Blooming Stimulation of Microcystis in Sutami Reservoir Using Nutrients Nitrate and Phosphate in Different ratio
}

\author{
Catur Retnaningdyah ${ }^{1 *}$, Suharjono ${ }^{1}$, Agoes Soegianto², Bambang Irawan ${ }^{2}$ \\ ${ }^{1}$ Department of Biology Faculty of Sciences University of Brawijaya , Malang, Indonesia \\ ${ }^{2}$ Department of Biology Faculty of Sciences and Technology University of Airlangga, Surabaya, Indonesia
}

\begin{abstract}
Microalgae Cyanobacteria from the genus Microcystis has the potential to bloom in Sutami reservoirs that located in Malang, Indonesia at a particular time. Microcystis is a notorious species because it can produce toxins that are dangerous to other organisms. The objective of this research is to determine the influence of different ratios of Nitrate and Phosphate on the growth of Microcystis in Sutami reservoir. The study was conducted from April to November 2009 and was carried out in situ in the reservoir Sutami with quasi experiment using a completely randomized design. Sutami reservoir water which already contained plankton community therein, including Microcystis were treated with five variations ratio of Nitrate and Phosphate (10, 20, 40, 80, and 160) and untreated water as control. Experiments carried out by using a transparent plastic bag diameter $1 \mathrm{~m}$ and $1.5 \mathrm{~m}$ long, inserted into the water and be immersed in the water by using bamboo. Calculation of Microcystis abundance and physic-chemical quality of water is done every three days for a month. The results showed that the higher concentration of orthophosphate in the media water of Sutami reservoir have the maximum abundance of Microcystis. Abundance of Microcystis grown in Sutami reservoirs have positively correlated with actual levels of nitrate, nitrite, total phosphate, conductivity, $\mathrm{pH}$, temperature, ratio of Nitrate to Phosphate treatment and water $\mathrm{KMnO}_{4}$ value.
\end{abstract}

Keywords: Blooming Microcystis, the ratio of nutrients Nitrate to Phosphate, Sutami reservoir

\section{Introduction}

Blooming populations of microalgae species especially Cyanobacteria from genus Microcystis occurred in 2002 in the Sutami reservoir located in the area of Malang, East Java, Indonesia [13]. Based on the monitoring results for the period from 2004 to March 2006, we found that Microcystis spp. with Synedra sp and Ceratium sp. always present in high abundances in the Sutami reservoir. An explosion of Microcystis population that often occurs in the Sutami reservoir could cause the death of fish that live in these waters [17]. The monitoring results of the Sutami reservoir water quality show that these waters were eutrophied and contaminated by organic materials [14]. Microcystis is a kind of blue-green algae (Cyanobacteria) usually grown on the surface of the water. In normal conditions Microcystis is not harmful to other organisms or humans. In certain conditions such as summer

\author{
*Corresponding address: \\ Catur Retnaningdyah \\ Biology Department, Brawijaya University \\ Jl. Veteran, Malang 65145, \\ East Java, Indonesia \\ Email : catur@ub.ac.id
}

with high nutrients (especially nitrate), species can grow rapidly commonly called algae blooms. In this blooming condition Microcystis can produce toxin called microcystin. Microcystin has a high toxicity to both the plants and animals can lead to death $[1,16,6,10,3,17]$.

Control of Microcystis blooming in the waters can be done by optimizing the potential of microbes in situ capable to reduce pollutants cause blooming. However, research on environmental factors that cause blooming in the waters of the tropics has not been studied. Results of research in the laboratory by [10] showed that the growth rate of Microcystis is positively influence by nitrate concentration and the maximal carrying capacity occurred when the phosphate concentration $0.4 \mathrm{ppm}$. Blooming of Microcystis can be triggered in B12 media with the ratio of nitrate: phosphate concentration were 20,40 or 80 as long as the content of phosphate in the media was $0.4 \mathrm{ppm}$ and nitrate content given in the media was higher along with the increasing of ratio

The results from sub trophic research in general can be concluded that the blooming of cyanobacteria tended to occur in lakes with a mass ratio of TN: TP is less than 29 which is generally referred to as "the rule TN: TP" [19,7]. 
The results of research in Sweden [20] indicated that Microcystis blooming influenced by the recruitment of Microcystis resting stages that are triggered by the high concentration of nutrients in combination ratio $\mathrm{N}$ : $\mathrm{P}$ is low at less than 10 . Conversely, a research on the lake at China [22] showed that the low ratio of TN: TP is not a cause of Microcystis blooming but as a result of these blooming. Blooming can occur in the ratio of TN: TP $<29$ or TN: TP $>29$ with nutrients $(\mathrm{N}, \mathrm{P})$ is quite high. Blooming can not occur in waters with low $\mathrm{P}$ concentrations, although the presence of $\mathrm{N}$ sufficient. Based on the above findings, especially the conflict results in the areas of research location and the there were no research information in similar studies in the tropics, therefore this research objective is to determine the response of Microcystis growth culturing together with other plankton communities in situ in the reservoir Sutami when treatment with various ratios of nitrate to phosphate. These results expected to be used as a basis to control Microcystis blooming in the waters.

\section{Research Method}

This research was conducted from August to November in 2009. by a quasi-experiment carried out in situ in the Sutami reservoir Malang East Java, Indonesia using complete randomized design. Water of Sutami reservoir which already contained plankton community therein, including Microcystis treated five variations of the concentration ratio of Nitrate to Phosphate and also controls from the water of Sutami reservoir which were not given the addition of nutrients.

Experiments carried out by using a transparent plastic bag diameter $1 \mathrm{~m}$ and $1.5 \mathrm{~m}$ long, inserted into the water and can be kept immersed in water by using bamboo. To keep the water around is not entered to the treatment so the plastic bags were made in such a way that approximately $10 \mathrm{~cm}$ from the plastic bag above the water surface. Meanwhile, to keep rain water can not enter into the treatment, the plastic is also provided which can be used to cover the treatment at any time it rains.

Sample $300 \mathrm{~L}$ of water which was already contains community of water organisms including Microcystis and other plankton taken at a depth of $0-50 \mathrm{~cm}$ was incorporated into each plastic bag given treatment the addition of Nitrate and Phosphate in the certain ratios. The ratio of 10 with addition $8 \mathrm{ppm}$ of nitrate and $0.8 \mathrm{ppm}$ phosphate. The ratio 20 with the addition of nitrate $8 \mathrm{ppm}$ and phosphate 0.4 $\mathrm{ppm}$. Ratio 40 with the addition of nitrate 16 ppm and phosphate $0.4 \mathrm{ppm}$. Ratio 80 with the addition of nitrate $32 \mathrm{ppm}$ and phosphate 0.4 $\mathrm{ppm}$. The ratio 160 with the addition of nitrate $32 \mathrm{ppm}$ and phosphate $0.2 \mathrm{ppm}$. As a control, we provided plastic bags that are not treated the addition of nutrients. For the comparison, besides conducted on the treatment and control, sampling was also conducted in the waters outside the treatment but in the Sutami reservoir. Incubation carried out in the reservoir Sutami for 30 days.

To determine the influence of nutrients and other plankton on the growth of Microcystis, then in each treatment were measured the water quality and calculated the Microcystis abundance once every three days to 30 days. After stirring in each treatment, we were sampling three liters of water using a water sampler vertical one-liter capacity. Water sample was accumulated from water taken at a depth of $+0-25 \mathrm{~cm}, 50-75 \mathrm{~cm}$ and $100-125 \mathrm{~cm}$ below the water surface. Some samples were used to measure the water quality of $\mathrm{pH}, \mathrm{DO}$, water temperature, conductivity, levels of nitrate, nitrite, ammonia, total Kjeldahl Nitrogen, total phosphate and $\mathrm{KMnO} 4$ values in a way according to [2].

Plankton sampling conducted by filtering 1 liter of water sample using a plankton net with a size of 406 pores per inch and a diameter of 12 $\mathrm{cm}$. Plankton samples be filtered into $15-\mathrm{mL}$ inserted into tube to be calculated the abundance of Microcystis cells according to [9].

Microcystis abundance data calculated from each day compiled and graphed the growth pattern. Microcystis abundance data used to calculate the maximum rate of growth $(\mathrm{g}=\mathrm{ln} \mathrm{Nt}-$ $\ln (0) / t$ ) and carrying capacity or the maximum abundance (K) of Microcystis which can be supported by the media treatment. The difference of maximum growth rate $(\mathrm{g})$ and maximum abundance of Microystis (K) between the treatments are known from the Anova test, followed by the Tukey HSD test performed with SPSS package for Windows release 13. Physicschemicals quality of measurement results were compiled in the table. The interaction between Microcystis with physics-chemicals factors were analyzed by Pearson correlation coefficients and multiple regressions.

\section{Results and Discussion}

Microcystis growth pattern that found in this research at various ratios nitrate to phosphate 
can be seen in Figure 1. Based on these images can be concluded that increasing the ratio of nitrate to phosphate caused the greater abundance of Microcystis which can be supported by the media. This is not appropriate with the opinion about "the rule TN: TP" $[19,7]$ which states that the blooming cyanobacteria tend to occur in lakes with a mass ratio of $\mathrm{TN}$ to $\mathrm{TP}$ is less than 29. And also not in accordance with the opinion [20] which showed that Microcystis blooming in Sweden triggered by the high concentration of nutrients in the combination of $\mathrm{N}$ to $\mathrm{P}$ ratio is lower than 10 .

The maximum abundance of Microcystis in the treatment ranging from $6.660 \times 10^{4} \mathrm{Cell} / \mathrm{mL}$ to $26.640 \times 10^{4} \mathrm{Cell} / \mathrm{mL}$. The treatment of this experiment could cause the blooming of Microcystis. It is because based on Verspagen (2006), it is said the blooming condition if the abundance of blooming Microcystis cells in waters more than 10.000 cells $/ \mathrm{mL}$.

The calculation result of maximum growth rate and carrying capacity can be seen in Figure 2. The maximum growth rate is not significance difference between the treatment but higher significantly if compared to control treatment. On the contrary, from Figure $2 \mathrm{~b}$ concluded that the higher of nitrate to phosphate ratio in natural water of Sutami reservoir caused the greater of the carrying capacity of Microcystis which can be supported by the media. It is mean that if the concentration of orthophosphate in the water is be the same, the blooming of Microcystis could be happened if the concentration of nitrate in the water is higher.

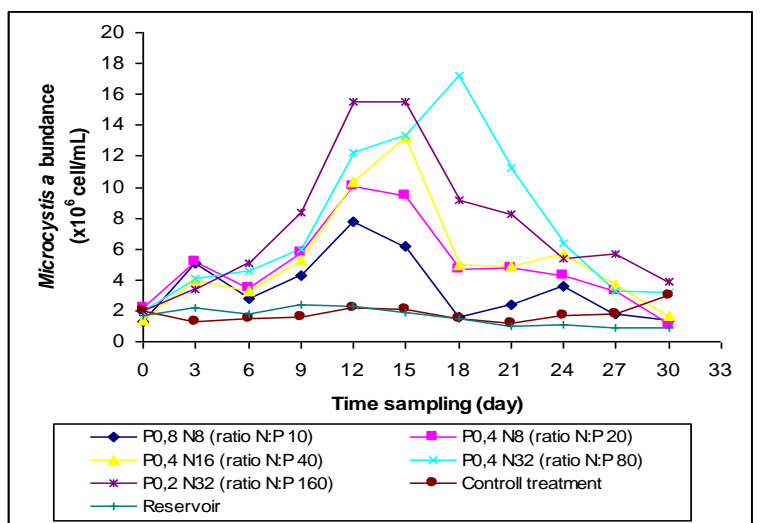

Figure 1. Growth pattern of Microcystis from Sutami reservoirs at various ratios nitrate to phosphate

Based on the calculation of Pearson correlation between environmental parameters with Microcystis abundance (Table 1), can be seen that the abundance of Microcystis in the reservoir
Sutami grown together with other plankton at various ratios of nitrate to phosphate positively correlated with actual levels of nitrate, $\mathrm{pH}$, conductivity, $\mathrm{KMnO}_{4}$ value, total phosphate, and nitrite. Based on multiple regression analysis shows that the abundance of Microcystis significantly affected by nitrate, $\mathrm{pH}$ and temperature of the media with positive influence with the following equation:

Abundance of Microcystis $=-59343.5^{* *}+78.1^{* *}$ (Nitrate) + 3332.1** $(\mathrm{pH})+1101.4^{*}$ (temperature) with the value of $\mathrm{R}^{2}=0.457$ and $\mathrm{R}=0.676$
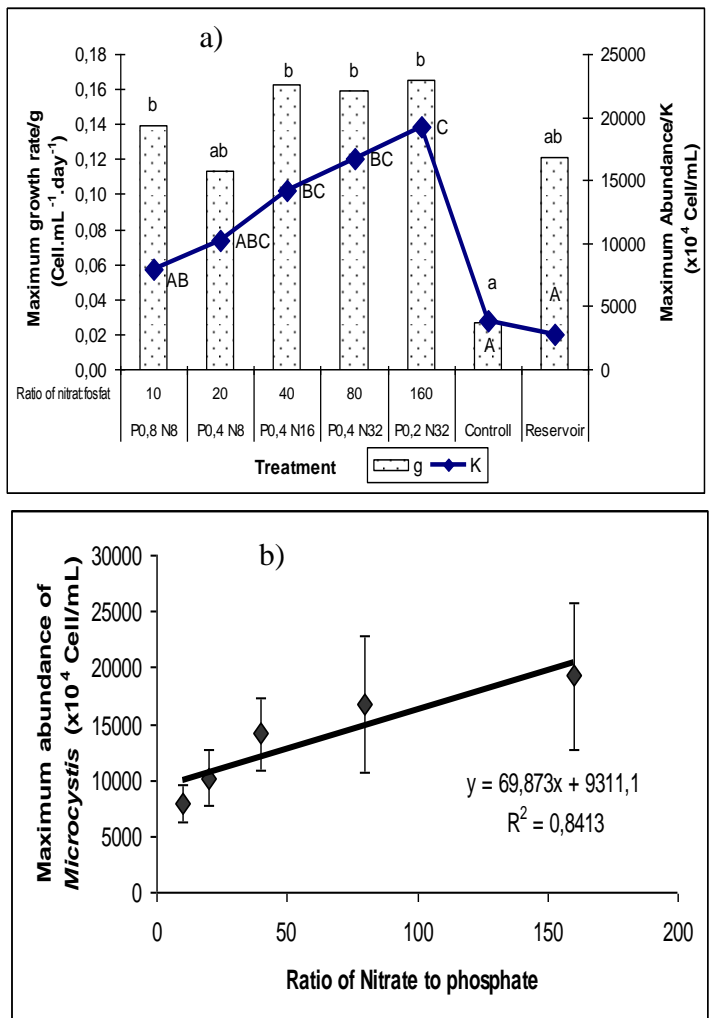

Figure 2. (a) Average of carrying capacity (K) and the maximum growth rate of Microcystis (g) each treatment; (b) Correlation between nitrate to phosphate ratio and the carrying capacity of Microcystis. Note: Different letter showed significance difference between $\mathrm{K}$ (capital letter) and $\mathrm{g}$ (lower case) based on Tukey HSD test at $\alpha 0.05)$

The statistical analyses showed that the main environmental parameters that affect the abundance or growth of Microcystis in the water is nitrate. The increasing of nitrate in the environment can trigger the growth of Microcystis that caused blooming. The result of study is suitable with the opinion which mentions that one of the causes of Microcystis blooming is the high nitrate [5]. According to [12], Microcystis is bio-indicator for eutrophic aquatic with high nitrate levels. Nitrate is a compound of polyatomic ions has an empirical formula $\mathrm{NO}_{3}$. 
Nitrate is formed when nitrogen from ammonia combines with the oxidized water. Nitrate is a form of soluble nitrogen compounds, formed through the oxidation process between the nitrogen and oxygen. The water organisms used nitrate as an energy source in producing new cells and colonies. Nitrate together with nitrite and ammonia is the main source of nitrogen for growth of microalgae, these used as the synthesis of amino acids and proteins [11].

Table 1. Pearson correlation coefficient values between Microcystis abundance with environmental factors (Note: * indicates significantly different at $\alpha 0.05$ and ${ }^{* *}$ at $\left.\alpha 0.01\right)$.

\begin{tabular}{|c|c|c|c|c|}
\hline Parameter & Mean & $\begin{array}{l}\text { Standard } \\
\text { Deviation }\end{array}$ & $\begin{array}{l}\text { Pearson } \\
\text { correlation } \\
\text { with } \\
\text { Microcystis }\end{array}$ & $\begin{array}{l}\text { Sig. } \\
\text { (2- } \\
\text { tailed) }\end{array}$ \\
\hline Nitrate (ppm) & 19,085 & 19,593 & $0,534^{\text {xix }}$ & 0,000 \\
\hline $\mathrm{pH}$ & 9,899 & 0,556 & $0,456^{\text {सz }}$ & 0,000 \\
\hline Conductivy (mS/cm) & 0,432 & 0,097 & $0,359^{\text {*i }}$ & 0,000 \\
\hline $\mathrm{KMNO}_{4}(\mathrm{ppm})$ & 5,128 & 0,633 & $0,284^{i \hbar}$ & 0,000 \\
\hline Total Phosphate/TP (ppm) & 0,147 & 0,152 & $0,234^{\text {*x }}$ & 0,003 \\
\hline Nitrite (ppm) & 0,535 & 0,547 & $0,215^{*}$ & 0,049 \\
\hline Total Kjeldahl Nitrogen/TKN (ppm) & 0,475 & 0,352 & 0,121 & 0,136 \\
\hline Ammonium (ppm) & 0,182 & 0,190 & 0,097 & 0,104 \\
\hline Ortophosphat (ppm) & 0,120 & 0,120 & 0,064 & 0,284 \\
\hline $\mathrm{D} 0$ (ppm) & 8,347 & 2,151 & 0,013 & 0,826 \\
\hline Temperature $\left.{ }^{\circ} \mathrm{C}\right)$ & 26,586 & 1,651 & $-0,019$ & 0,747 \\
\hline Actual ratio TKN:TP & 21,268 & 39,803 & $-0,115$ & 0,157 \\
\hline
\end{tabular}

Based on the correlation analysis found that the total phosphate levels correlated positively to the abundance of Microcystis and did not significance correlate with the level of orthophosphate. Phosphate levels in the water needed to trigger the occurrence of blooming is low. In this study, phosphate is required to trigger rapid growth of Microcystis was $0.4 \mathrm{ppm}$. This result was suitable with the opinion of [18], that in the aquatic ecosystem elements of phosphorus (P) is the limiting nutrient. Therefore, if all phosphorus is used so the growth of organisms will be decrease though other nutrients abundant. Meanwhile, if sufficient phosphorus availability, the increased concentration of nitrate will trigger blooming alga. $\mathrm{P}$ element is a vital nutrient for algae growth. In the cellular activity, the element phosphorus is needed for energy transfer, the author of nucleic acids and cell membrane phospholipids [4]. Meanwhile, algae in general needs of the phosphorus are much lower than the need for carbon and nitrogen (106C: $16 \mathrm{~N}$ : 1P). If the ratio of $\mathrm{N}$ and $\mathrm{P}$ availability is $30: 1$, the phosphorus will be exhausted before all the nitrogen used. Whereas if the ratio of $\mathrm{N}$ and $\mathrm{P}$ availability is $6: 1$, then the nitrogen will quickly become exhausted and inhibited algae growth [8].

\section{Conclusions and Recommendations}

The results showed that increasing the ratio of nitrate to orthophosphate ratio in natural media water of Sutami reservoir caused greater the maximum abundance of Microcystis which can be supported by the media. The abundance of Microcystis in the reservoir Sutami grown together with other plankton at various ratios of nitrate to phosphate positively correlated with actual levels of nitrate, $\mathrm{pH}$, conductivity, $\mathrm{KMnO}_{4}$ value, total phosphate, and nitrite. Blooming Microcystis in the water reservoir Sutami levels can occur in high concentration of nitrate waters with a high ratio of nitrate to soluble phosphate.

These results can then be used as the basis for the regulation of nutrients in the waters for inhibition of Microcystis blooming in the waters. We recommend to control level of nitrate with orthophosphate content less than $0.4 \mathrm{ppm}$ to inhibit Microcystis blooming in the Sutami.

\section{Acknowledgments}

This research is supported by Directorate General of Higher Education, Ministry of National Education (National Strategic Research Grant in 2009) and collaboration with PT. Jasa Tirta.

\section{References}

[1] Barnes RSK, Mann KH. Fundamentals of Aquatic Ecology. Blackwell Science. London. 1991. 270 pages.

[2] Clesceri LS, Greenberg AE, Eaton AD. Standard Methods for the Examination of Water and Waste Water. 20th Ed., Washington. 1998.

[3] Closs G, Downes B, Boulton A. A Scientific Introduction Freshwater Ecology. Blackwell Publishing. Malden USA. 2006.

[4] Davis ML, Masten SJ. Principles of Environmental Engineering and Science. McGraw-Hill companies, Inc. New York. 2004.

[5] Dokulil MT, Teubner K. Cyanobacterial Dominance in Lakes. Hydrobiologia. 2000; 438:1-12

[6] Ferrão-Filho AS, Domingos P, Azevedo SMFO, Influences of a Microcystis aeruginosa Kützing bloom on zooplankton populations in Jacarepaguá Lagoon (Rio de Janeiro, Brazil), Limnologica, 2002; 32:295-308

[7] Fujimoto N, Sudo R. Nutrient-limited growth of Microcystis aeruginosa and Phormidium tenue and competition under various N:P supply ratios and temperatures. Limnol. Oceanogr., 1997; 42(2):250-256 
[8] Heathwaite L, Phil H, Rachel D. Pathways of Phosphorus Transport in Agriculture and phosphorus management: the Chesapeaks Bay. editor Sharpley A.N . CRC Press. Boca Raton. 2000.

[9] Joung SH, Kim CJ, Ahn CY, Jang KY, Boo SM, Oh HM. Simple method for a cell count of the colonial Cyanobacterium Microcystis sp. The Journal of Microbiology. 2006; 44(5):562-565

[10] Oberholster PJ, Botha, Grobbelaan. Microcystis spp. : Source of Toxic Mikrocystins in Drinking Water. African Journal of Biotechnology 2004; 3(3):159 - 168.

[11] Qiang Hu, Westerhoff P, Vermaas W. Removal of Nitrate from Grounwater by Cyanobacteria: Quantitative Assesement of Factors Influencing Nitrate Uptake. Applied and Environmental Microbiology. 2000.

[12] Ramirez JJ, Bicudo CEM. Diurnal and Spatial (Vertical) Dynamics of Nutrients (N, P, Si) in Four Sampling Days (Summer, Fall, Winter and Spring) in A Tropical Shallow Reservoir and Their Relationships with The Phytoplankton Ccommunity. Braæ: J. Biol. 2005; 65(1): 141-157

[13] Retnaningdyah C, Prayitno, Rosyitawati Y, Dewi MYC, Hartini AN. The Potentially of Microalgae as Bioindicator of Organic Materials Pollution Level in Water Reservoir. National Seminar on Research and Studies Research Grant conducted by the Ministry of National Education, Directorate General of Higher Education, TPSDP, Jakarta December 27-28, 2002.

[14] Retnaningdyah C. Interaction Analyses between Water Quality and the Population Dynamics of Microcystis spp. in Reservoir Sutami, Malang, East Java. Proceedings National Seminar of Limnology IV, organized by the Research Center for LimnologyLIPI, Bogor, October 15, 2008.
[15] Retnaningdyah C, Suharjono, Soegianto A, Irawan B Growth Response of Microcystis Isolated from Sutami Reservoir at Various of Nitrate and Phosphate in B12 Medium, Proceedings National Seminar on Basic Science VII , organized by Science Faculty Brawijaya University, Malang, Pebruary 20, 2010

[16] Romanowska-Duda Z, Mankiewicz J, Tarczyńska M, Walter Z, Zalewski M. The Effect of Toxic Cyanobacteria (Blue Green Algae) on Water Plants and Animal Cells. Polish Journal of Environmental Studies. 2002; 11(5):561-566

[17] Samino S, Retnaningdyah C. Evaluation the Toxicity of Microcystis toward some Indigenous fish from Sutami reservoir. Cooperation Research Reports Perum Jasa Tirta I and the Department of Biology Faculty of Sciences University of Brawijaya Certificate No. ID03/0127. 2006.

[18] Sharpley AN. Agriculture and phosphorus management: the Chesapeaks Bay. CRC Press LLc. Boca Raton 2003

[19] Smith VH. Low nitrogen to phosphorus ratios favor dominance by blue-green algae in lake. Science. 1983 221:669-671

[20] Stahl-Delbanco A, Hansson LA, Gyllstrom M. Recruitment of resting stages may induce blooms of Microcystis at low N:P ratios. J. of Plankton Research. 2003; 25(9):1099-1106

[21] Verspagen JMH. Benthic-Pelagic Coupling in the Population Dynamics of the Cyanobacterium Microcystis. Ph.D Thesis. Universiteit Utrecht, Nederlands. 2006.

[22] Xie L, Xie P, Li S, Tang H, Liu H. The low TN:TP ratio, a cause or a result of Microcystis blooms?. Water Research 2003; 37: 2073-208 